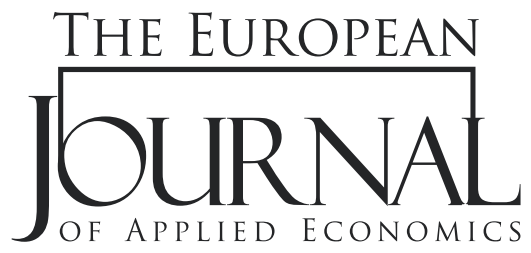

EJAE 2020, 17(2): $54-66$

ISSN 2406-2588

UDK: 338.21:620.91

502.171:620.9

DOI: 10.5937/EJAE17-26902

Original paper/Originalni naučni rad

\title{
CONCEPTUALIZING INTEGRATED POLICYMAKING: DOES THE DIVERSIFICATION OF ENVIRONMENTAL POLICY INSTRUMENTS CONTRIBUTE TO INCREASED SUSTAINABILITY?
}

\author{
Vlastimir Vučić*, Miljana Radović Vučić \\ SMC Swiss Management Center AG, \\ Zug, Switzerland
}

\begin{abstract}
:
Most urgent societal issues are crosscutting the boundaries of established jurisdiction. The conventional environmental policy domain is unable to achieve environmental objectives by itself, and each policy sector must integrate environmental objectives. For instance, the lack of clarity of how the integration of environmental objectives into energy policy has transformed and modified energy policy is the reason behind the low levels of integrated policy-making achieved. The present research attempts to clarify how the diversification of environmental policy instruments contributes to integrated policy-making. The present research explicitly confirms that that an increase in the extent of inclusion of environmental policy instruments within relevant policy domains increases to the extent of diversification of environmental policy instruments; that an increase in the extent of inclusion of environmental policy instruments within relevant policy domains and structures that coordinate and monitor efforts within relevant policy domains increases to the extent of diversification of environmental policy instruments; and, that an increase in the extent of inclusion of environmental policy instruments within relevant policy domains ultimately resulting in a cross-sectoral instrument blend results in the increase in the extent of diversification of environmental policy instruments.
\end{abstract}

\section{Article info:}

Received: Jun 8, 2020

Correction: August 3, 2020

Accepted: September 12, 2020

\section{Keywords:}

Sustainable development (SD), environmental policy integration (EPI), renewable electricity (RES-E), policy instruments, integrated policymaking.

\section{INTRODUCTION}

Most severe societal issues over health, food, energy, transport, climate, innovations, freedom, etc., are crosscutting the boundaries of established jurisdiction, namely through policy domains and governance levels. Increasing requirements for integrated policymaking over these issues are apparent; however, obstacles for integrated policymaking, such as inappropriate instrument mixes, competing attention over issues, competing and incoherent objectives, fragmentation, compartmentation, etc., are making it harder to achieve. 
These obstacles gain in relevance when these societal issues are confronted with hierarchical governance and its traditional forms of subsystem involvement.

In hierarchical governance and its traditional forms of subsystem involvement, policymaking takes place with a relatively stable set of actors, each of whom displays a set of beliefs, interests, and perceptions, and which genuinely do not allow for an integrated policymaking approach towards these issues. To further add to the complexity of integrated policymaking, the number of actors taking part in the policymaking has increased, namely due to increasing emphasis on public participation of private industry, public administration, interest groups, civil society, the general public, etc.

Most severe societal issues that are crosscutting the boundaries of established jurisdiction link the incompatible objectives of economic competitiveness, social development, and environmental protections with the concept of sustainability or sustainable development (SD). Furthermore, these severe issues thus link the incompatible objectives of integrating concerns of environmental protection with economic competitiveness and social development or Environmental policy integration (EPI). Therefore, one of the most important illustrations of SD can be observed as its emphasis on the inclusion or integration of environmental concerns or objectives into policy domains that are not related to the domain of conventional environmental policy. The claims for the inclusion or integration of environmental concerns or objectives into policy domains that are not related to the domain of conventional environmental policy are found in the thorough literature review (see, for instance, Adelle and Russel, 2013; Jordan and Lenschow, 2010; Mullally and Dunphy, 2015; Runhaar et al., 2014; Runhaar et al., 2017; Solorio, 2011; Söderberg, 2011; Uittenbroek et al., 2013; Wamsler, 2015; Wejs, 2014). Accordingly, it has been revealed explicitly that the conventional environmental policy domain is not able to achieve environmental objectives by itself, and that each policy sector must take into consideration and integrate environmental objectives if these objectives are to be achieved in any way. The literature, thus, explicitly views EPI as a necessary modification of policymaking to guide society as a whole in a more sustainable manner.

Similarly, societal issues over the energy sector are, thus, crosscutting the boundaries of established jurisdiction, namely through policy domains and governance levels. Apart from the more general literature which, for instance, illustrates that the integration of environmental concerns or objectives into energy policy is a stance upon which the European Union (EU) governs its energy-related issues (see, for instance, Solorio, 2011), the more explicit literature reveals reasons for studying the energy sector in the context of the present research: $\mathrm{CO}_{2}$ emission reductions, economic impacts, and energy security (see, for instance, IEA, 2019). Another important reason for studying the energy sector in the context of the present research is certainly the potential of renewable electricity (RES-E) (Knudsen 2010, 2012).

Another important matter illustrated by the literature in general is that there is a lack of clarity on how the integration of environmental concerns or objectives into energy policy has transformed and modified energy policy. For this reason, modest levels of integrated policy-making in the energy sector, as well as in sectors policy domains that are not related to the domain of conventional environmental policy, have so far been achieved.

The present research thus aims to clarify how the integrated policymaking adds value to the diversification of environmental policy instruments and inclusion or integration of environmental concerns or objectives into the policy domain of energy. 


\section{LITERATURE REVIEW}

\section{Conceptualizing Integrated Policymaking}

EPI became the most important concept in environmental governance with the publication of the Brundtland report in 1987, which defined the SD as a "development that meets the needs of the present without compromising the ability of future generations to meet their own needs" (WCED, 1987, p. 2), illustrating that the integration of economic competitiveness, social development, and environmental protection is central to the concept of SD. Following the publication of the Brundtland Report, the integration was officially recognized as a principle of international law. For instance, EPI was legally accepted by the Treaty on European Union (EU) in 1993, and incorporated into the Treaty establishing the European Community (TEC), prescribing integration of environmental protection into the EU's relevant policies and activities, most explicitly about the promotion of sustainability.

Similarly, to properly understand European integration development, it is necessary to understand the role energy has played in this process. It is rather difficult to explain the creation of the EU without taking into consideration the creation of the European Coal Organization (ECO) in 1946 and the Organization for European Economic Co-operation (OEEC) in 1948, obviously showing that energy was a foundation of European integration. A similar motivation is found behind the creation of the European Coal and Steel Community (ECSC) in 1952 and the European Atomic Energy Community (EURATOM) in 1958, constituting the basic pillars of the European Economic Community (EEC). Moreover, a similar motivation is found behind the Élysée Treaty signed in 1963 between France and Germany, aimed at reconciliation of relationship, which was later anchored in the EU. However, despite efforts, the integration process has not developed sufficiently enough to form a basis for a common energy policy. It was not until the Lisbon reform in 2009 and the Treaty on the Functioning of the European Union (TFEU) that brought the necessary changes to this sector and set the policy goals, otherwise known as energy trinity, i.e., security of supply, affordable energy, and environmental sustainability. The commencement of the "Cardiff Process" in 1998 illustrates a step forward towards the practical application of EPI with Renewable Energy Sources (RES) and energy efficiency forming the basis of a sustainable energy system, and with the 2020 Climate and Energy Package adopted in 2009 is largely viewed as the flagship instrument of the EU's forward-looking perspective on this sustainable energy model (Oberthür and Pallaemarts, 2010). The package involves a 20 percent reduction in greenhouse gas (GHG) emissions (from 1990 levels), 20 percent of energy from RES, and a 20 percent improvement in energy efficiency. Similarly, a new science-policy-society interface for the 2030 Agenda emphasizes the role of European Advisory Councils on the Environment and SD. Accordingly, the 2030 Climate and Energy Framework adopted in 2014 involves a 40 percent reduction in GHG emissions (from 1990 levels), 32 percent of energy from RES, and a 32.5 percent improvement in energy efficiency. In addition, the implementation of the 2030 Agenda at the national, sub-national, and local level necessitates a strong association between the most important actors, namely governments, the scientific community, and a broad variety of actors. The European Advisory Councils on the Environment and SD play an important role in terms of knowledge dissemination and agenda setting.

\section{Framework for the Analysis of Integrated Policymaking}

EPI is defined as "the incorporation of environmental objectives into all stages of policymaking in non-governmental policy sectors, with specific recognition of this goal as a guiding principle for the planning and execution of policy" (Lafferty and Hovden, 2003, p. 9). Furthermore, this principle should 
be "accompanied by an attempt to aggregate presumed environmental consequences into an overall evaluation of policy, and a commitment to minimize contradictions between environmental and sectoral policies by giving principled priority to the former over the latter" (Lafferty and Hovden, 2003, p. 9). A similar term to EPI is climate policy integration (CPI) (Jordan and Lenschow, 2010). Even though there are different meanings linked to CPI, the notion is the same as that of EPI.

EPI strategies found in the literature are relatively diverse, and range from regulatory and financial to institutional and organizational. Likely due to such a diverse nature of these strategies, an overview of EPI is virtually non-existent. Some of the most frequent examples include Strategic Environmental Assessment (SEA), Environmental Impact Assessment (EIA), Green budgeting, Green taxes, Biodiversity conservation markets, Environmental units within sectoral departments, Green departments, Combination of departments, and Environmental reporting obligations, Sustainable development strategies (SDS), National environmental plans, etc. EPI strategies also include partnerships between public and private actors, voluntary sector-wide agreements between public and private actors, voluntary sectoral self-governance, municipal voluntarism, self-organized and self-governed management. The literature also illustrates different frameworks on of how to measure levels of EPI achieved (see for instance Weber and Driessen, 2010; Dupont and Oberthür, 2012), generally distinguishing the following levels of integrated policymaking: coordination, harmonization, and prioritization, or more recent studies (see, for instance, Uittenbroek et al., 2013; Brouwer et al., 2013), generally distinguishing the following levels of integrated policymaking: inclusion, consistency, weighting, and reporting. Broadly speaking, the performance of EPI strategies could be evaluated in terms of physical indicators, such as a reduction of climate risks, $\mathrm{CO}_{2}$ emissions, environmental quality, etc. (see Adelle and Russel, 2013). However, given that such evaluation would be rather difficult to take place, the reported levels of EPI found in the mentioned literature relate to EPI strategies that are influential in decision-making or policymaking, as well as in the implementation of these decisions or policies.

Evaluative EPI strategies are found in the literature focusing on particular policy sectors and in different countries: noise and spatial planning (Weber and Driessen, 2010), bioenergy policy (Söderberg, 2011), water policy (Brouwer et al., 2013), urban planning (Uittenbroek et al., 2013), etc. Evaluative EPI strategies are also found focusing on the performance of particular strategies: sustainable development strategies (Steurer and Hametner, 2013), green budgeting (Russel and Benson, 2013), market-based mechanisms, such as cap and trade systems, green taxes and biodiversity conservation markets (Ward and Cao, 2012; Lu et al., 2012; Alvarado - Quesada et al., 2014), etc.

Furthermore, the literature points to the governance of EPI as the most important obstacle in decisionmaking or policymaking. In trade-offs, sectoral and environmental issues and concerns necessarily come into conflict and there is a lack of political will to prioritize environmental issues and concerns (see Dupont and Oberthür, 2012). The literature points to the implementation of EPI as another obstacle, because relevant institutions and bodies, such as governmental ministries, lack the resources, power, and authority to enforce EPI (see Dupont and Oberthür, 2012). Lists of factors that ease or constrain EPI are also found in more general literature: cultural, instrumental, economic, organizational, and political factors, as well as in empirical research: contextual, procedural and organizational factors (Weber and Driessen, 2010), political factors, network, skills, personal motivation, relationships between policy sectors and organizational factors, decision-making, the characteristics of the actors, the outcomes of the environmental assessment, the legal basis (Arts et al., 2012), entry and exit barriers, transaction costs, complete information, appropriate actors, and property rights (Alvarado-Quesada et al., 2014). Similarly, lists of factors that ease or constrain CPI are also identified: institutional, socio-cultural, cognitive, knowledge and informational, and financial factors (Biesbroek et al., 2013). 


\section{Policy Framing as a Method of Learning in Integrated Policymaking}

EPI strategies found in the literature can also be observed from an institutional perspective (see, for instance, Wejs, 2014; Wejs and Cashmore, 2014; Wejs et al., 2014), in which it is emphasized that finding the appropriate discourse is necessary to gain legitimacy for EPI. According to the particular research, framed as a mechanism of socio-economic development, climate change is less difficult to integrate than framed as an environmental problem. The literature has already widely endorsed a policy-learning approach to analyzing integrated policymaking, illustrating the increasing focus on the role of a new science-policy-society interface, necessitating a strong association between the most important actors, namely governments, the scientific community, and a broad variety of actors. The implication of learning in policymaking contributes to a change in the policy process and policymaking, which can be viewed as a precondition for sustainability. Broadly speaking, learning is possible by adapting to changing conditions and acquiring new knowledge based on experience gained through the policy process. Thus, in contrast to hierarchical governance and its traditional forms of subsystem involvement, the policy-learning approach to analyzing integrated policymaking implies that policy is created in networking processes with both public and private actors that have different ideas and interests. Policy networks can, therefore, subsequently be described as informal structures, enabling communication and interaction between actors.

To avoid any potential ambiguity involved with the policy-learning approach to analyzing integrated policymaking, a unifying concept of policy framing is introduced. According to Rein and Schön (1993, p. 146), "framing is a way of selecting, organizing, interpreting, and making sense of a complex reality to provide guideposts for knowing, analyzing, persuading and acting". Moreover, "a frame is a perspective from which an amorphous, ill-defined, problematic situation can be made sense of and acted on" (Rein and Schön, 1993, p. 146). Policy frames can thus help interpret environmental requirements as a mechanism toward the achievement of environmental protection and market harmonization in general.

Lenschow and Zito (1998) analyze how policy frames have influenced the manner the European Community (EC) actors understand the integration of environmental and economic policy objectives. They argue that there are three EC policy frames: conditional, classic, and sustainability, illustrating how the integration of environmental and economic policy objectives takes place. The conditional environmental policy frame conceptualizes the EC environmental regulation to prevent trade distortions produced by the diverging national environmental standards rather than to create a European environmental policy regime. The conditional environmental policy frame thus assumes that environmental and economic policy function independently from one another, and that policymaking must be necessarily viewed as a choice between incompatible objectives of environmental and economic policy. Several regulatory features follow such an assumption, and are observable in an explicitly hierarchical structure of administration, according to which EC is distinguished as the primary actor in the economy to create harmonized market conditions. According to this frame, environmental regulations and standards are applied uniformly within EU member states, which implies the use of command-and-control policy instruments. The classic environmental policy frame conceptualizes the EU environmental regulation to increase environmental awareness in terms of limiting safety, health, and environmental risks, requiring policy compromise. Environmental and economic policies continue to function independently from one another, however. The EU is still viewed as the primary actor in the market aiming to create harmonized market conditions with command-and-control policy instruments remaining uniformly applied within EU member states. The sustainability policy frame no longer assumes that environmental and economic policy function independently from one another, and acknowledges 
policy compromises as a necessary condition for long-term economic development. Decision-making or policymaking thus applies the principle of partnership and integrated policymaking, which prescribe the internalization of environmental costs in market transactions, i.e., economic policy instruments, self-regulation, learning tools, etc.

\section{Policy Instruments and Integrated Policymaking}

The principle of integrated policymaking thus suggests the internalization of environmental costs in market transactions, i.e., economic policy instruments. Economic policy instruments or market-based policy instruments are mechanisms that recommend conduct through explicit market indications. As such, market-based policy instruments prescribe both firms and individuals undertaking pollution control efforts that are in their interest, and also to fulfill policy requirements. Market-based policy instruments of the sustainability policy frame, therefore, contrast other environmental regulations and standards of the conditional and classic policy frames, which are applied uniformly within EU member states. Environmental regulations and standards with a uniform application are inclined to force firms to assume similar shares of the pollution control burden, irrespective of the cost, which can be expensive and counterproductive. In contrast, by providing incentives for the reductions in pollution by those firms which can achieve those reductions in the cheapest possible manner, market-based policy instruments allow any desired level of pollution control effort to be achieved at the lowest possible cost for society. Market-based policy instruments thus have the potential to provide powerful incentives for firms to obtain cheaper and improved pollution-control technologies. Market-based policy instruments can be considered within four broad categories: government subsidy reductions, market friction reductions, tradable permits, and pollution charges.

Within the context of market-based policy instruments, the literature illustrates an increasing interest in the design of subsidy regimes to accommodate the adequate development of RES-E. Accordingly, subsidy regimes can be considered within two broad approaches: direct and indirect (Batlle et al., 2011). Direct approaches refer to investment support, such as support mechanisms, tax reductions capital grants, etc. A feed-in tariff (FIT) is an example of a direct approach and support mechanism. Indirect approaches refer to institutional support mechanisms and implicit payments, such as positive discriminatory rules, below-cost provision of infrastructure, funding of research and development, etc.

\section{METHODOLOGY}

\section{The Development of the Research Hypotheses}

The present research has obtained the research hypothesis based on the literature review. The main research hypothesis can be summarized as follows:

H1: The higher the extent of inclusion of environmental policy instruments within relevant policy domains, the higher the extent of diversification of environmental policy instruments.

H2: The higher the extent of inclusion of environmental policy instruments within relevant policy domains and structures that coordinate and monitor efforts within relevant policy domains, the higher the extent of diversification of environmental policy instruments.

H3: The higher the extent of inclusion of environmental policy instruments within relevant policy domains ultimately resulting in cross-sectoral instrument blend, the higher the extent of diversification of environmental policy instruments. 


\section{Research Designs}

Sekaran and Bouqie (2009, p.3) define business research as "organized, systematic, data-based, critical objective, specific inquiry or investigation into a specific problem, undertaken to find answers or solutions to it." The present research can thus be understood as a process of finding a solution to an issue after a thorough study and analysis of the various actors.

Given that there are no earlier studies or analyses to refer to the subject, the present research will, therefore, look for patterns and ideas to create hypotheses. The hypotheses will be tested and confirmed. It is expected that the hypotheses will not only provide conclusive answers to the subject, but also provide guidance on what future research should be conducted.

The present research will use a survey as a research technique. The present research will use e-post, on-line, face-to-face, group distribution, and individual distribution as data collection methods. The survey was taken from January $15^{\text {th }}, 2020$ to February $15^{\text {th }}$, 2020. A sample for the data collection includes EU institutions and bodies (namely, the European Council and the European Commission), academic institutions (public and private universities), and private investors (investment funds and venture capitalists). Approximately 700 questionnaires were distributed in order to obtain the desired number of 100 confirmed respondents. The present research will also use descriptive statistics to summarize the data in a more compact and graphical form.

Furthermore, the present research is designed to apply its findings to solve a specific problem. It represents the application of existing knowledge to the improvement of public policies and managerial practices.

Finally, the present research is research in which a conceptual and theoretical structure is developed, which is then tested by empirical observation. Particular instances are, thus, deducted from general inferences.

\section{ANALYSIS}

H1: The higher the extent of inclusion of environmental policy instruments within relevant policy domains, the higher the extent of diversification of environmental policy instruments.

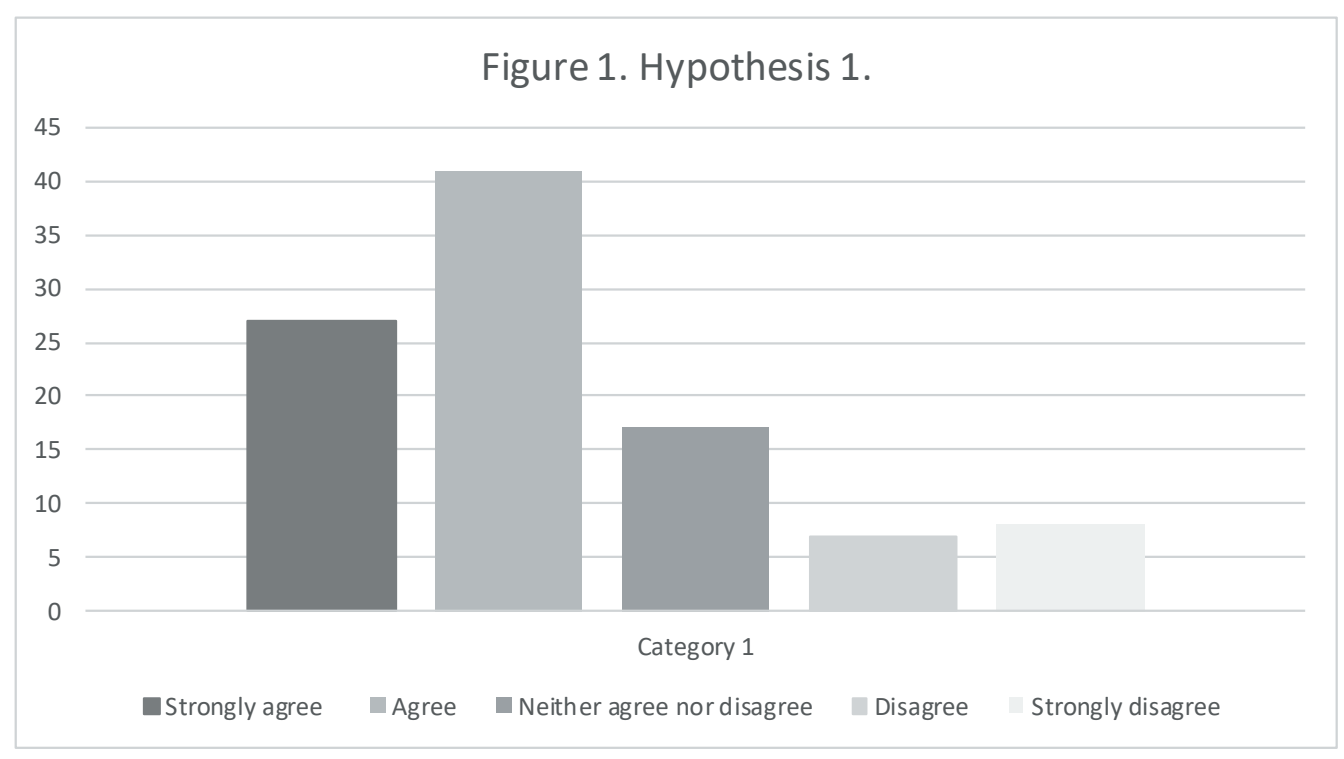

Source: Compiled by the author (2020) 
Approximately 700 questionnaires were distributed in order to obtain the desired number of 100 confirmed respondents. The statistics show that 27 percent of the respondents strongly agree that an increase in the extent of inclusion of environmental policy instruments within relevant policy domains increases to the extent of diversification of environmental policy instruments. Accordingly, another 41 percent of the respondents agree with said statement, followed by 17 percent, who neither agree nor disagree, 7 percent who disagree, and 8 percent who strongly disagree.

H2: The higher the extent of inclusion of environmental policy instruments within relevant policy domains and structures that coordinate and monitor efforts within relevant policy domains, the higher the extent of diversification of environmental policy instruments.

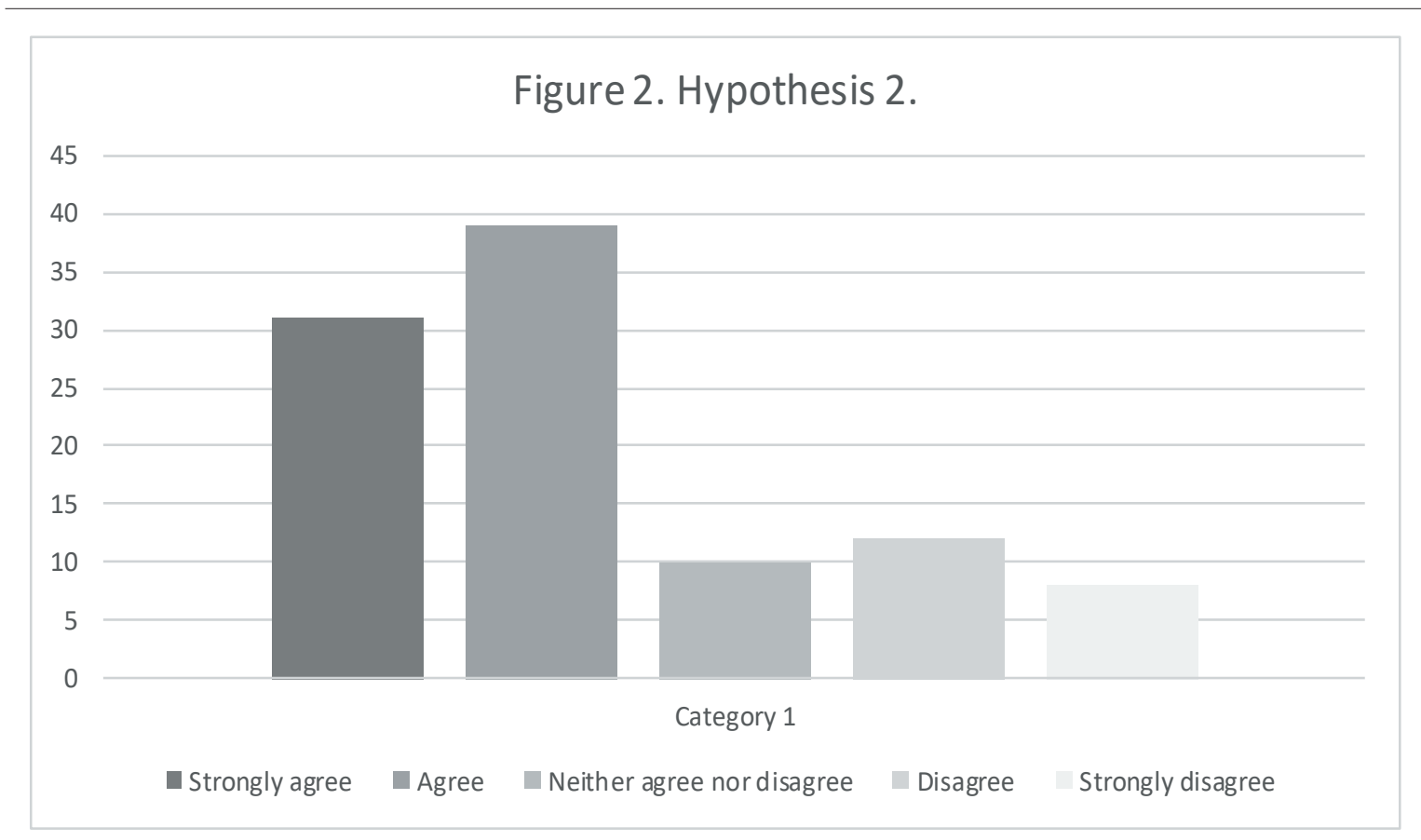

Source: Compiled by the author (2020)

Approximately 700 questionnaires were distributed in order to obtain the desired number of 100 confirmed respondents. The statistics illustrate that 31 percent of the respondents strongly agree that an increase in the extent of inclusion of environmental policy instruments within relevant policy domains and structures that coordinate and monitor efforts within relevant policy domains increases to the extent of diversification of environmental policy instruments. Another 39 percent of the respondents agree with said claim, followed by 10 percent who neither agree nor disagree, 12 percent who disagree, and 8 percent who strongly disagree. 
H3: The higher the extent of inclusion of environmental policy instruments within relevant policy domains ultimately resulting in cross-sectoral instrument blend, the higher the extent of diversification of environmental policy instruments.

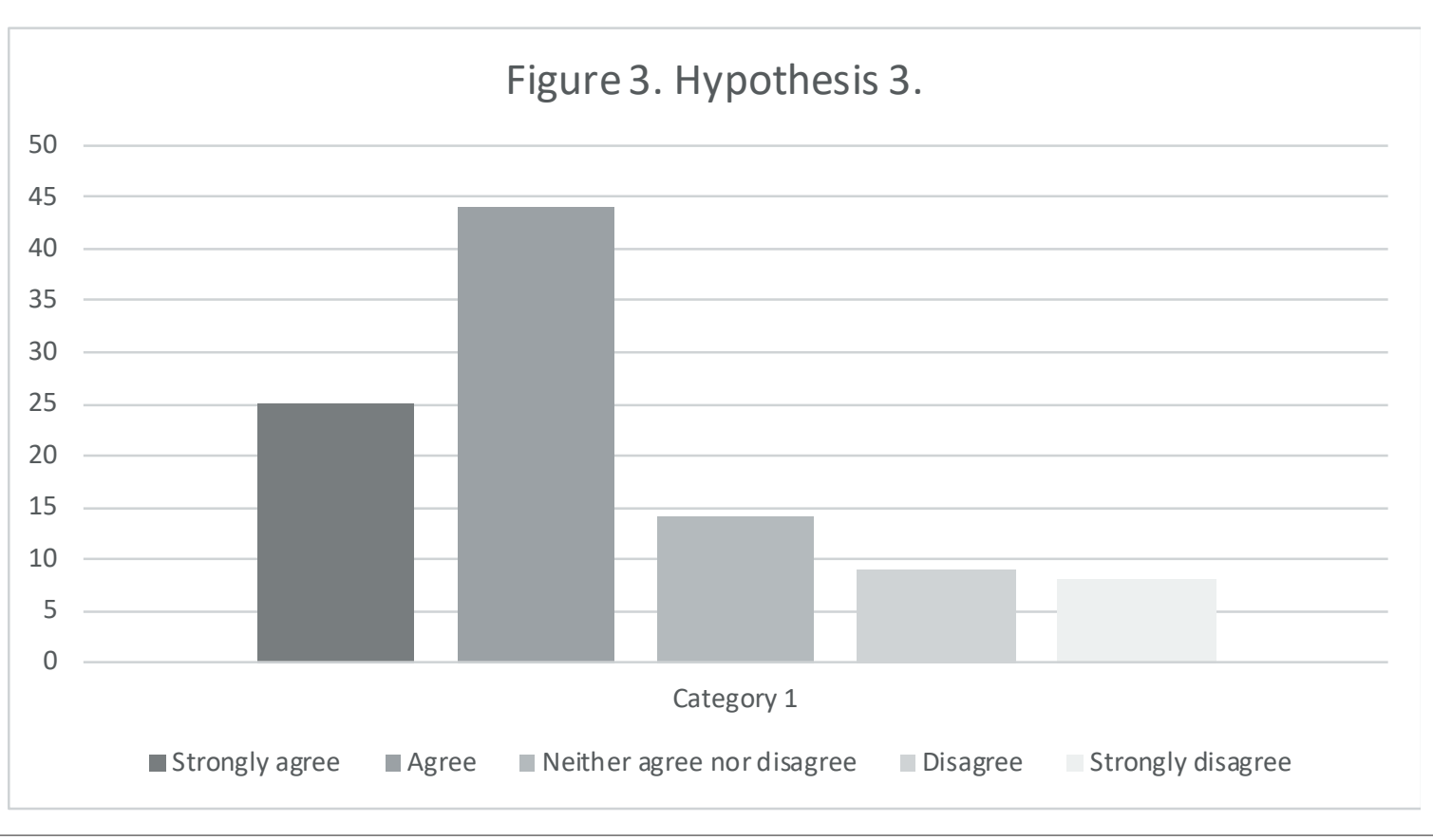

Source: Compiled by the author (2020)

Approximately 700 questionnaires were distributed in order to obtain the desired number of 100 confirmed respondents. The statistics display that 25 percent of the respondents strongly agree that an increase in the extent of inclusion of environmental policy instruments within relevant policy domains ultimately resulting in a cross-sectoral instrument blend results in the increase in the extent of diversification of environmental policy instruments. Accordingly, 44 percent of the respondents agree with said claim, followed by another 14 percent who neither agree nor disagree, 9 percent who disagree, and 8 percent who strongly disagree.

\section{CONCLUSION}

Most severe societal issues are crosscutting the boundaries of established jurisdiction through policy domains and governance levels. Even though there are increasing requirements for integrated policymaking of these issues, obstacles for integrated policymaking are making it increasingly difficult to achieve it, particularly when these societal issues are confronted with hierarchical governance and its traditional forms of subsystem involvement. To add to the complexity of integrated policymaking, the number of actors involved in the policymaking has increased.

Most severe societal issues that are crosscutting the boundaries of established jurisdiction connect the incompatible objectives of economic competitiveness, social development, and environmental protections with the concept of SD, and link the incompatible objectives of integrating concerns of environmental protection with economic competitiveness and social development or EPI. 
Therefore, one of the most important illustrations of SD is the inclusion or integration of environmental concerns or objectives into policy domains that are not related to the domain of conventional environmental policy, i.e., EPI. The necessity for the inclusion or integration of environmental concerns or objectives into policy domains that are not related to the domain of conventional environmental policy are found in the thorough literature review, which reveals the inability of the conventional environmental policy domain to achieve environmental objectives by itself, and that each policy sector must take into consideration and integrate environmental objectives if they are anyhow to be achieved. The literature, therefore, views EPI as a necessary modification of policymaking to guide society as a whole in a more sustainable manner.

In a similar manner, societal issues over the energy sector are crosscutting the boundaries of established jurisdiction, namely through policy domains and governance levels. The literature reveals that, within the context of the present research, the energy sector is very important due to how the EU governs its energy-related issues, as well as due to more explicit reasons, such as the $\mathrm{CO}_{2}$ emission reductions, economic impacts, and energy security, and to the potential of RES-E.

The lack of clarity on how the integration of environmental concerns or objectives into energy policy has transformed and modified energy policy is the main reason behind the modest levels of integrated policy-making in the energy sector achieved. The present research thus attempts to clarify how the integrated policymaking adds value to the diversification of environmental policy instruments and inclusion or integration of environmental concerns or objectives into the policy domain of energy.

Accordingly, in H1, 68 percent of the respondents either strongly agree or agree that an increase in the extent of inclusion of environmental policy instruments within relevant policy domains increases to the extent of diversification of environmental policy instruments. In $\mathrm{H} 2,70$ percent of the respondents either strongly agree or agree that an increase in the extent of inclusion of environmental policy instruments within relevant policy domains and structures that coordinate and monitor efforts within relevant policy domains increases to the extent of diversification of environmental policy instruments. In H3, 69 percent of the respondents strongly agree that an increase in the extent of inclusion of environmental policy instruments within relevant policy domains ultimately resulting in a cross-sectoral instrument blend results in the increase in the extent of diversification of environmental policy instruments.

Within the context of the present research, any attempt to diversify environmental policy instruments can be seen from the perspective of integrated policymaking as a deliberate and structured effort by policymakers to deal with the policy issue by modifying actions of the integrated policymaking. 


\section{REFERENCES}

Adelle, C. and Russel D. (2013). Climate Policy Integration: a case of déjà vu? Environmental Policy and Governance. 23(1), 1-12.

Albertini, E. (2015). What we know about environmental policy: an inductive typology of the research. Business Strategy and Environment 26(3), 277-297.

Alvarado-Quesada, I., Hein, L. and Weikard, H-P. (2014). Market-based mechanisms for biodiversity conservation: a review of existing schemes and an outline for a global mechanism. Biodiversity and Conservation 23(1), 1-21.

Arts, J., Runhaar, H. A. C., Fischer, T. B., Jha-Thakur, U., van Laerhoven, F., Driessen, P. P. J. and Onyango, V. (2012). The effectiveness of EIA as an instrument for environmental governance: a comparison of 25 years of EIA practice in the Netherlands and the UK. Journal of Environmental Assessment Policy and Management 14(4) special issue on 25 years of EIA in the EU. https://doi.org/10.1142/S1464333212500251.

Batlle, C., Pérez -Arriaga, I.J. and Zambrano-Barragán, P. (2011). "Regulatory design for RES-E support mechanisms: learning curves, market structures and burden - sharing. Energy policy 41, 212 - 220.

Brouwer, S., Rayner, T. and Huitema D. (2013). Mainstreaming climate policy: the case of climate adaptation and the implementation of EU water policy. Environment and Planning C: Government and Policy 31(1), 134-153

Buizer, M., Arts, B. and Westerink, J. (2015). Landscape governance as policy integration “from below": a case of displaced and contained political conflict in the Netherlands. Environment and Planning C: Government and Policy. 34(3), 448-462.

Cleaver, F. (2012). Development Through Bricolage: Rethinking Institutions for Natural Resource Management. Routledge, New York, NY, USA.

Dupont, C. and Oberthür, S. (2012). Insufficient climate policy integration in EU energy policy: the importance of the long-term perspective. Journal of Contemporary European Research 8(2), 228-247.

IEA. (2019). World Energy Outlook: Analysis, Paris: International Energy Agency.

Jordan, A. and Lenschow, A. (2010). Environmental policy integration: a state-of-the-art review. Environmental Policy and Governance. 20(3), 147-158.

Henry, A. D. and Dietz, T. (2012). Understanding environmental cognition. Organization and Environment 25(3), $238-258$.

Hogl, K., Kleinschmit, D. and Rayner, J. (2016). Achieving policy integration across fragmented policy domains: forests, agriculture, climate and energy. Environment and Planning C: Government and Policy. 34(3), 399-414.

Knudsen, J. K. (2010). Integrating environmental concerns in a trans-Atlantic perspective: The case of renewable electricity, Review of Policy Research 27(2): 127 - 146.

Knudsen, J. K. (2012). Renewable energy and environmental policy integration: Renewable fuel for the European energy policy?, in F. Morata and I. S. Sandoval (eds), European Energy Policy: An Environmental Energy Approach (Cheltenham, Edward Elgar), pp. 48 - 65.

Lafferty, W.M. and Hovden. E. (2003). Environmental policy integration: towards an analytical framework, Environmental Politics 12(3): 1-22.

Lenschow, A. and Zito, A. (1998). 'Blurring or shifting of policy frames? Institutionalization of the economicenvironmental policy linkage in the European Community, Governance: An International Journal of Policy and Administration 11(4), 415-442.

Lu, Y., Zhu, X. and Cui, Q. (2012). Effectiveness and equity implications of carbon policies in the United States construction industry. Building and Environment 49, 259-269.

Millner, A. and Ollivier, H. (2016). Beliefs, politics and environmental policy. Review of Environmental and Economic Policy. 10(2), 226-244.

Mullally, G. and N. Dunphy (2015). . State of play review of Environmental Policy Integration literature. Cork: National Economic and Social Council, University College Cork: Cork. 
Mundaca, L., Neij, L., Markandya, A., Hennicke, P. and Yan, J. (2016). Towards a green economy? Assessing policy choices, strategies and transitional pathways. Applied Energy 179,1282-1292.

Oberthür, S. and M. Pallemaerts. (2010). The EU's internal and external climate policies: an historical overview, in S. Oberthür and M. Pallemaerts (eds), The New Climate Policies of the European Union: Internal Legislation and Climate Diplomacy (pp. 27 - 63), Brussels: VUB Press.

Persson, Å., Eckerberg, K. and Nilsson, M. (2016). Institutionalization or wither away? Twenty-five years of environmental policy integration under shifting governance models in Sweden. Environment and Planning C: Government and Policy. 34(3), 478-495.

Persson, Å., Runhaar, H., Karlsson-Vinkhuyzen, S., Mullally, G., Russel, D. and Widmer, A.(2018). Editorial: environmental policy integration: taking stock of policy practice in different contexts. Environmental Science \& Policy. 85,113-115.

Rein, M., and Schön, D. A. (1993). Reframing policy discourse, In F. Fischer and J. Forester (eds), The argumentative turn in policy analysis and planning (pp. 27 - 63). Durham, North Carolina, USA: Duke University Press.

Runhaar, H., Driessen, P.J.J. and Uittenbroek, C. (2014). Towards a systematic framework for the analysis of Environmental Policy Integration. Environmental Policy and Governance, 24(4), 233-246.

Runhaar, H., Bettina W., Åsa P., Caroline U. and Christine W. (2017). Mainstreaming Climate Adaptation: Taking Stock about "What Works" from Empirical Research Worldwide. Regional Environmental Change, 18, 1201-1210.

Russel, D. and Benson, A. (2013). Green budgeting in an age of austerity: a transatlantic comparative perspective. Environmental Politics, 23(2), 243-262.

Sekaran, U. and Bougie, R. (2009). Research Methods for Business: A Skill-Building Approach (5 ${ }^{\text {th }}$ Edition,). Hoboken, New Jersey, USA: John Wiley and Sons Inc.

Solorio, I. (2011). Bridging the Gap between Environmental Policy Integration and the EU's Energy Policy: Mapping out the 'Green Europeanisation' of Energy Governance. Journal of Contemporary European Research, 7(3), 396-415.

Steurer, R. and Hametner, M. (2013). Objectives and indicators in sustainable development strategies: Similarities and variances across Europe. Sustainable Development. 21(4), 224-241.

Söderberg, C. (2011). Institutional conditions for multi-sector environmental policy integration in Swedish bioenergy policy, Environmental Politics, 20(4), 528-546.

Uittenbroek, C. J., Janssen-Jansen, L. B. and Runhaar, H. A. C. (2013). Mainstreaming climate adaptation into urban planning: overcoming barriers, seizing opportunities and evaluating the results in two Dutch case studies. Regional Environmental Change, 13, 399-411.

Wamsler, C. (2015). Mainstreaming Ecosystem-based Adaptation: Transformation Toward Sustainability in Urban Governance and Planning. Ecology and Society, 20(2):30. Available at: http://dx.doi.org/10.5751/ ES-07489-200230.

Ward, H. and Cao, X. (2012). Domestic and international influences on green taxation. Comparative Political Studies, 45(9), 1075-1103.

Weber, M. and Driessen, P. P. J. (2010). Environmental policy integration: the role of policy windows in the integration of noise and spatial planning. Environment and Planning C: Government and Policy, 28(6), 1120-1134.

Wejs, A. (2014). Integrating climate change into governance at the municipal scale: an institutional perspective on practices in Denmark. Environment and Planning C: Government and Policy, 32(6), 1017-1035.

Wejs, A. and Cashmore, M. (2014). Constructing legitimacy for climate change planning: a study of local government in Denmark. Global Environmental Change, 24(1), 203-212.

Wejs, A., Harvold, K., Larsen, S. V. and Saglie, I. L. (2014). Legitimacy building under weak institutional settings: Climate change adaptation at the local level in Denmark and Norway. Environmental Politics, 23(3), 490-508.

World Commission on Environment and Development: Our Common Future. (1987). Oxford, UK: Oxford University Press. 


\section{KONCEPIRANJE INTEGRISANOG KREIRANJA POLITIKE: \\ DA LI DIVERSIFIKACIJA INSTRUMENATA ZAŠTITE ŽIVOTNE SREDINE MOŽE DA DOVEDE DO POVEĆANJA ODRŽIVOSTI SAME POLITIKE?}

\section{Rezime:}

Najteža društvena pitanja prelaze granice uspostavljene nadležnosti. Konvencionalni domen politike zaštite životne sredine ne može sam da ostvari ciljeve zaštite životne sredine i zato svaki domen politike individualnih sektora mora da uzme u obzir i integriše ciljeve zaštite životne sredine. Na primer, nedostatak jasnoće kako je integracija odredbi ili ciljeva zaštite životne sredine transformisala i modifikovala energetsku politiku glavni je razlog za postignute skromne nivoe integrisanog kreiranja politika. Sadašnje istraživanje pokušava da razjasni kako diversifikacija instrumenata politike zaštite životne sredine doprinosi integrisanom kreiranju politika. Sadašnje istraživanje izričito potvrdjuje da se povećava stepen uključivanja instrumenata politike zaštite životne sredine u relevantne domene politika do stepena diversifikacije instrumenata politike zaštite životne sredine; da se povećava stepen uključivanja instrumenata politike zaštite životne sredine u relevantne domene politika i struktura koje koordiniraju i prate napore unutar relevantnih domena politike povecava do stepena diversifikacije instrumenata politike zastite zivotne sredine; i da se povećava stepen uključivanja instrumenata politike zaštite životne sredine u relevantne domene politika i medjusektorskom mešavinom instrumenata do stepena diversifikacije instrumenata politike zaštite životne sredine.
Ključne reči:

Održivi razvoj (OR),

Integracija politike zaštite životne sredine,

Energija iz obnovljivih izvora, Instrumenti politike, Integrisano kreiranje politike. 